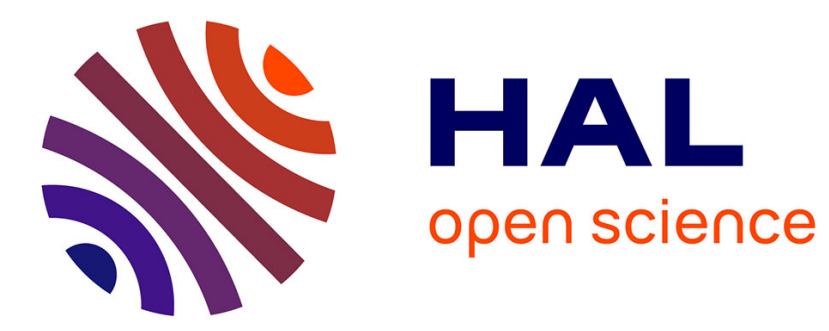

\title{
Low-irradiance red light compared to conventional red light in photodynamic therapy of actinic keratosis: a way to reduce pain during treatment
}

Serge Mordon, Anne-Sophie Vignion-Dewalle

\section{- To cite this version:}

Serge Mordon, Anne-Sophie Vignion-Dewalle. Low-irradiance red light compared to conventional red light in photodynamic therapy of actinic keratosis: a way to reduce pain during treatment. Dermatologic Therapy, 2019, 10.1111/dth.12913 . hal-02555761

\author{
HAL Id: hal-02555761 \\ https://hal.science/hal-02555761
}

Submitted on 27 Apr 2020

HAL is a multi-disciplinary open access archive for the deposit and dissemination of scientific research documents, whether they are published or not. The documents may come from teaching and research institutions in France or abroad, or from public or private research centers.
L'archive ouverte pluridisciplinaire HAL, est destinée au dépôt et à la diffusion de documents scientifiques de niveau recherche, publiés ou non, émanant des établissements d'enseignement et de recherche français ou étrangers, des laboratoires publics ou privés. 
Low-irradiance red light compared to conventional red light in photodynamic therapy of actinic keratosis: a way to reduce pain during treatment

Serge Mordon, PhD. (https://orcid.org/0000-0002-1208-7153)

Anne Sophie Vignion-Dewalle, PhD.(https://orcid.org/0000-0003-0979-3310)

Address: INSERM, Univ. Lille, CHU Lille, U1189-OncoThAI-Image Assisted Laser Therapy for Oncology, Lille, F-59000, France.

Electronic address: serge.mordon@inserm.fr.

No funding

Conflict of interest: The authors have no conflict of interest to declare

Text word count: 584

Number of references: 9

Tables: 1

Figures: 2 


\section{Low-irradiance red light compared to conventional red light in photodynamic therapy of actinic keratosis: a way to reduce pain during treatment}

Conventional photodynamic therapy (C-PDT), which requires an irradiation with $37 \mathrm{~J} / \mathrm{cm}^{2}$ of red light after 3 hours of Methyl aminolevulinate incubation is an effective protocol, approved in Europe, for thin and non-pigmented AK on the face and scalp(Pariser et al., 2008; Szeimies et al., 2009). However C-PDT is associated with high pain scores (Morton et al., 2006; Rubel et al., 2014; Wiegell et al., 2008). This letter aims to review and discuss clinical studies (Table 1) dealingwith PDT involving irradiation with low-irradiance (lower than $20 \mathrm{~mW} / \mathrm{cm}^{2}$ ) red light (Li-PDT).

In 2012, Ibbotson et al evaluated the Ambulight $^{\circledR}$ device emitting $7 \mathrm{~mW} / \mathrm{cm}^{2}$ red light (Ibbotson \& Ferguson, 2012). Twenty three patientsreceived both C-PDTand Ambulight which was programmed to remain switched off for threehours and then to switch on automatically and remain on for a further threehours. The mean pain score for was 1 (minimum: 0; maximum: 7) for PDT using the Ambulight ${ }^{\circledR}$ device and 5 (minimum: 1.5; maximum: 9) for C-PDT.At one year, lesion clearance rate was $84 \%$.

Gholam et al have alsoevaluated Li-PDT using the BF-RhodoLED ${ }^{\circledR}$ lamp system with an irradiance of $15.4 \mathrm{~mW} / \mathrm{cm}^{2}$ for40 minutes in order to achieve a lightdose of $37 \mathrm{~J} / \mathrm{cm}^{2}$. Thirty-one patientswere enrolled (Gholam, Bosselmann, Enk, \& Dick, 2018).Li-PDT resulted in significant less pain scores than C-PDT(2.8 for Li-PDT vs 7.6 for C-PDT) while maintaining a similar efficacy four weeks after treatment: percentage reduction of $69.9 \%$ for Li-PDT vs $74.3 \%$ for C-PDT.

Vicentini et al performed a study evaluating PDT using a light-emitting fabric device delivering fractionated red light at a low irradiance of $12 \mathrm{~mW} / \mathrm{cm}^{2}$ (Li-PDT)(Vicentini et al., 2018). After 30 minutes of MAL incubation, the Li-PDT devicewas switched on and illumination was performed for $2 \mathrm{~h} 30$ giving a lightdose of $37 \mathrm{~J} / \mathrm{cm}^{2}$. With a mean pain score of 0.4 , Li-PDT was found to be almost pain free compared to C-PDT (5.0). Efficacy was $84 \%$ for \% Li-PDT and $76.8 \%$ for C-PDT at6 month-follow up.

The 3 studiesfound a significant and clinically relevant reduction inpain for Li-PDT compared to CPDTatthe samelight dose. The data reported by these three studies were pooled in order to evaluate the relationship between irradiance $\left(\mathrm{mW} / \mathrm{cm}^{2}\right)$ and pain (Figure 2). A linear relationship was observed with a coefficient of determination (R-squared) of 0.726 .

It is usually admitted that pain is correlated with PpIX production. Regarding daylight-PDT, it is presumed that continuous production and photoactivation of small amounts of PpIX instead of fast photo activation of large amounts decreases pain (Wiegell et al., 2008). This explains that pain score 
reported in Study \#3 where pain (0.4) is lower than those reported in Studies \#1 $\left(7 \mathrm{~mW} / \mathrm{cm}^{2}\right.$; pain: 1.0) and \#2 (15 mW/ $\mathrm{cm}^{2}$; pain: 2.8). In Study \#3, illumination was performed after 30minutes of incubation whereas the two others studies uses an incubation time of 3 hours. Martin found that a 15 minutes incubation resulted in significantly less pain than a 75 minutes incubation time (Martin, 2016).Comparatively, Daylight PDT is associated to pain scores, typically around 2.0(Wiegell et al., 2012).

In conclusion, since pain is always reported as the main drawback of C-PDT, irradiation with low irradiance red light should be considered by dermatologists. The controlled light delivery of Li-PDT is an advantage over daylight-PDT, which has also been explored as a less painful means to deliver PDT. However, the limitation of continuous low irradiance is prolonged treatment times.

Compared to daylight-PDT, Li-PDT consistently delivers the same light dose and can be conducted in all weather conditions, in all geographic locations, all year round. 


\section{References}

Gholam, P., Bosselmann, I., Enk, A. H., \& Dick, J. (2018). Low irradiance compared with conventional photodynamic therapy in the treatment of actinic keratoses. Photodermatol Photoimmunol Photomed. doi:10.1111/phpp.12431

Ibbotson, S. H., \& Ferguson, J. (2012). Ambulatory photodynamic therapy using low irradiance inorganic light-emitting diodes for the treatment of non-melanoma skin cancer: an open study. Photodermatol Photoimmunol Photomed, 28(5), 235-239. doi:10.1111/j.16000781.2012.00681.x

Martin, G. M. (2016). In-office Painless Aminolevulinic Acid Photodynamic Therapy: A Proof of Concept Study and Clinical Experience in More Than 100 Patients. J Clin Aesthet Dermatol, 9(2), 19-26.

Morton, C., Campbell, S., Gupta, G., Keohane, S., Lear, J., Zaki, I., . . . Investigators, A. K. (2006). Intraindividual, right-left comparison of topical methyl aminolaevulinate-photodynamic therapy and cryotherapy in subjects with actinic keratoses: a multicentre, randomized controlled study. Br J Dermatol, 155(5), 1029-1036. doi:10.1111/j.1365-2133.2006.07470.x

Pariser, D., Loss, R., Jarratt, M., Abramovits, W., Spencer, J., Geronemus, R., . . Bruce, S. (2008). Topical methyl-aminolevulinate photodynamic therapy using red light-emitting diode light for treatment of multiple actinic keratoses: A randomized, double-blind, placebo-controlled study. J Am Acad Dermatol, 59(4), 569-576. doi:10.1016/j.jaad.2008.05.031

Rubel, D. M., Spelman, L., Murrell, D. F., See, J. A., Hewitt, D., Foley, P., ... Shumack, S. (2014). Daylight photodynamic therapy with methyl aminolevulinate cream as a convenient, similarly effective, nearly painless alternative to conventional photodynamic therapy in actinic keratosis treatment: a randomized controlled trial. Br J Dermatol, 171(5), 1164-1171. doi:10.1111/bjd.13138

Szeimies, R. M., Matheson, R. T., Davis, S. A., Bhatia, A. C., Frambach, Y., Klovekorn, W., ... Thaci, D. (2009). Topical methyl aminolevulinate photodynamic therapy using red light-emitting diode light for multiple actinic keratoses: a randomized study. Dermatol Surg, 35(4), 586-592. doi:10.1111/j.1524-4725.2009.01096.x

Vicentini, C., Vignion-Dewalle, A. S., Thecua, E., Lecomte, F., Maire, C., Deleporte, P., . . Mortier, L. (2018). Photodynamic therapy for actinic keratosis of the forehead and scalp: a randomized controlled clinical study evaluating the non-inferiority of a new protocol applying irradiation with a light-emitting, fabric-based device (the Flexitheralight protocol) compared to the conventional protocol using the Aktilite CL 128 lamp. Br J Dermatol, Accepted.

Wiegell, S. R., Haedersdal, M., Philipsen, P. A., Eriksen, P., Enk, C. D., \& Wulf, H. C. (2008). Continuous activation of PpIX by daylight is as effective as and less painful than conventional photodynamic therapy for actinic keratoses; a randomized, controlled, single-blinded study. $\mathrm{Br}$ J Dermatol, 158(4), 740-746. doi:10.1111/j.1365-2133.2008.08450.x

Wiegell, S. R., Wulf, H. C., Szeimies, R. M., Basset-Seguin, N., Bissonnette, R., Gerritsen, M. J., . . . Braathen, L. R. (2012). Daylight photodynamic therapy for actinic keratosis: an international consensus: International Society for Photodynamic Therapy in Dermatology. J Eur Acad Dermatol Venereol, 26(6), 673-679. doi:10.1111/j.1468-3083.2011.04386.x 


\section{Table}

\begin{tabular}{|c|c|c|c|c|c|c|}
\hline Author & Comparative study & $\begin{array}{l}\text { Number of } \\
\text { patients }\end{array}$ & $\begin{array}{l}\text { Duration } \\
\text { illumination }\end{array}$ & Light dose & Pain & $\begin{array}{c}\text { Efficacy } \\
\text { (\% reduction) }\end{array}$ \\
\hline $\begin{array}{l}\text { Gholam(Gholam } \\
\text { et al., 2018) }\end{array}$ & $\begin{array}{c}\left.\text { RhodoLED } 15.4 \mathrm{~mW} / \mathrm{cm}^{2}\right) \\
\text { vs } \\
\text { Aktilite }\left(66.2 \mathrm{~mW} / \mathrm{cm}^{2}\right)\end{array}$ & $\begin{array}{c}31 \\
\text { Actinic } \\
\text { Keratosis } \\
\text { Grade I - III }\end{array}$ & $\begin{array}{c}40 \text { minutes } \\
\text { vs } \\
9 \mathrm{~min} \text { and } 19 \mathrm{~s}\end{array}$ & $\begin{array}{l}37 \mathrm{~J} / \mathrm{cm}^{2} \\
\mathrm{vs} \\
37 \mathrm{~J} / \mathrm{cm}^{2}\end{array}$ & $\begin{array}{l}2.8 \pm 1.5 \\
\text { vs } \\
7.6 \pm 1.5\end{array}$ & $\begin{array}{c}\text { At } 1 \text { month FU } \\
67.9 \pm 11.8 \\
\text { vs } \\
69.9 \pm 2.1\end{array}$ \\
\hline $\begin{array}{l}\text { Vicentini } \\
\text { (Vicentini et al., } \\
\text { 2018) }\end{array}$ & $\begin{array}{c}\text { Flexitheralight } 12 \mathrm{~mW} / \mathrm{cm}^{2} \\
\text { vs } \\
\text { Aktilite }\left(65 \mathrm{~mW} / \mathrm{cm}^{2}\right)\end{array}$ & $\begin{array}{c}25 \\
\text { Actinic } \\
\text { Keratosis } \\
\text { Grade I - II }\end{array}$ & $\begin{array}{l}50 \text { minutes } \\
\text { vs } \\
9 \mathrm{~min} \text { and } 50 \mathrm{~s}\end{array}$ & $\begin{array}{l}37 \mathrm{~J} / \mathrm{cm}^{2} \\
\mathrm{vs} \\
37 \mathrm{~J} / \mathrm{cm}^{2}\end{array}$ & $\begin{array}{l}0.4 \pm 0.6 \\
\text { vs. } \\
5.0 \pm 2.6\end{array}$ & $\begin{array}{c}\text { At } 6 \text { month FU } \\
84.0 \% \\
\text { vs } \\
76.8 \%\end{array}$ \\
\hline $\begin{array}{l}\text { Ibbotson(Ibbots } \\
\text { on \& Ferguson, } \\
\text { 2012) }\end{array}$ & $\begin{array}{c}\text { Ambulight }\left(7 \mathrm{~mW} / \mathrm{cm}^{2}\right) \\
\text { Vs } \\
\text { Aktilite }^{\circledR}\left(80-90 \mathrm{~mW} / \mathrm{cm}^{2}\right)\end{array}$ & $\begin{array}{c}23 \\
\text { small } \\
\text { lesions of } \\
\text { Bowen's } \\
\text { disease } \\
\text { and } \\
\text { superficial } \\
\text { BCC }\end{array}$ & $\begin{array}{l}180 \text { minutes } \\
\text { vs } \\
20 \text { minutes }\end{array}$ & $\begin{array}{l}75 \mathrm{~J} / \mathrm{cm}^{2} \\
\mathrm{vs} \\
75 \mathrm{~J} / \mathrm{cm}^{2}\end{array}$ & $\begin{array}{c}1.0(0-7) \\
\text { vs } \\
5.0(1.5-9)\end{array}$ & $\begin{array}{c}\text { At } 1 \text { year FU } \\
84 \% \\
\text { vs } \\
?\end{array}$ \\
\hline
\end{tabular}

Table 1: Data reported for the clinical studies included in the review: from refs: (Vicentini et al., 2018)(Ibbotson \& Ferguson, 2012)(Gholam et al., 2018). Grade I Actinic Keratosis are slightly palpable, grade II are moderately thick, and grade III AK are very thick and/or obvious

\section{Figures}

Figure 1: Light-emitting fabric device (from ref (Vicentini et al., 2018)

Figure 2: Pain scores (0-10) vs Irradiance $\left(\mathrm{mW} / \mathrm{cm}^{2}\right)$. Data were obtained from refs: (Vicentini et al., 2018)(Ibbotson \& Ferguson, 2012)(Gholam et al., 2018) 